\title{
"O poder que ainda não está no poder": Paulo Freire, pedagogia crítica e a guerra na educação pública - uma entrevista com Ira Shor
}

\section{"The power not yet in power": Paulo Freire, critical pedagogy and the war on public education - an interview with Ira Shor}

\author{
Ira Shor ${ }^{1}$ \\ Alexandre Saul ${ }^{2}$ \\ Ana Maria Saul ${ }^{2}$
}

\begin{abstract}
RESUMO
Ira Shor é professor da City University of New York's Graduate Center (Phd Program in English) e no Departamento de Inglês do College of Staten Island (CSI). O Dr. Shor tem se dedicado ao ensino de alunos da graduação e pós-graduação, na perspectiva da educação crítica. O trabalho de Shor com Freire teve início em 1980 e se estendeu até 1997. Ambos são coautores do primeiro livro falado de Paulo Freire intitulado, no Brasil, Medo e ousadia: o cotidiano do professor. Nesta entrevista, concedida aos professores Alexandre Saul e Ana Maria Saul, o professor Shor discute a importância da pedagogia crítica na formação de professores, diante de um cenário global de crescente conservadorismo e adoção de políticas públicas de educação neotecnicistas, que contribuem para obstaculizar a autonomia das escolas e dos professores. Ele diz da atualidade do pensamento de Paulo Freire como uma possibilidade factível de construção de uma educação pública e democrática no bojo da qual a formação de professores precisa se fazer
\end{abstract}

DOI: $10.1590 / 0104-4060.46863$

1 Programa de Pós-Graduação em Inglês da City University of New York. 2800 Victory Blvd, Staten Island, NY 10314.E-mail: professorishor@gmail.com

2 Entrevistadores: Pontifícia Universidade Católica de São Paulo. Programa de Estudos Pós-Graduados em Educação. São Paulo, São Paulo, Brasil. Rua Ministro Godói, $n^{\circ} 969-4^{\circ}$ andar, sala 4E-15. CEP: 05.015-000.E-mails: anasaul@uol.com.bre asaul@hotmail.com 
com diálogo, respeito aos diferentes conhecimentos e formas de conhecer, horizontalidade nas relações humanas e indissociabilidade entre teoria e prática. Ira Shor destaca que, para Paulo Freire, a construção de um mundo mais justo, para todos, necessita de uma utopia que tenha raízes bem plantadas na história. Enfatiza a impossibilidade da neutralidade da educação e a necessidade da conscientização para transformação da realidade.

Palavras-chave: Paulo Freire; pedagogia crítica; formação de professores; educação pública.

\begin{abstract}
Ira Shor is a professor at the City University of New York's Graduate Center (Programa Phd em Inglês) and at the English Department at the College of Staten Island (CSI). Dr. Shor has been dedicated to teaching undergraduate students and graduate students from the perspective of critical education. The work of Shor with Freire began in 1980 and lasted until 1997. Both are co-authors of the first talking book by Paulo Freire, called in Brazil Fear and boldness: the teacher's daily life. In this interview, with Professors Alexandre Saul and Ana Maria Saul, Professor Shor discusses the importance of critical pedagogy on teacher education, in the face of a global setting of increasing conservatism and adoption of educational public policies of a neo-technicist character, which contribute to hinder the autonomy of schools and teachers. He highlights the pertinence and timeliness of the thought of Paulo Freire as a feasible possibility of building public and democratic education in the midst of which teacher education has to be done with dialogue, respect for different types of knowledge and ways of knowing, horizontality in human relations and inseparability between theory and practice. Ira Shor points out that, for Paulo Freire, the construction of a more equal world for all, would need a kind of utopia that has well planted roots in history. He emphasizes the impossibility of education neutrality and the need of awareness to transform reality.
\end{abstract}

Keywords: Paulo Freire; critical pedagogy; teacher education; public education.

\title{
Apresentação
}

No atual momento do país, no qual a luta em defesa da democracia se torna mais necessária para garantir a legalidade institucional e conquistas sociais, a pedagogia crítica se mostra cada vez mais relevante porque, ao incidir sobre 
PROF. DR. IRA SHOR

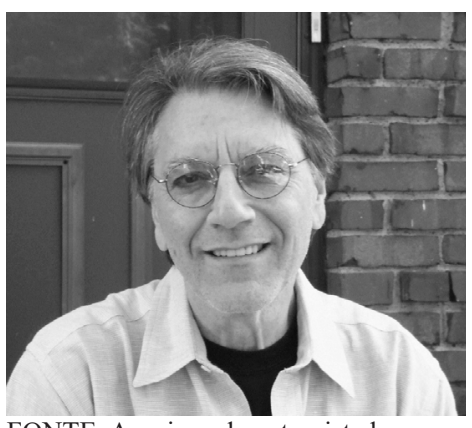

FONTE: Arquivos do entrevistado.

a realidade concreta, contribui para o seu desvelamento e nos desafia para transformar a ordem social injusta. No bojo dessa compreensão, a formação de educadores assume papel relevante no projeto de sociedade que se quer construir, uma vez que se espera que os professores possam atuar no espectro de uma educação que valorize a solidariedade, a cooperação e a organização coletiva.

Faz-se necessário superar a lógica positivista, que inverte a relação teoria-prática, subordinando esta última à primeira, e afirma o poder de quem possui "o saber", sustenta a forma desumanizadora de tratar os educadores e a sua formação, e se torna ainda mais perversa, ao incorporar características do capitalismo neoliberal. As abordagens e metodologias "importadas" do espaço da economia e das finanças e aplicadas às políticas e práticas de educação e à formação docente disseminam a cultura da meritocracia nas escolas, estimulando o reprodutivismo e o individualismo entre os educadores, por meio da distribuição de bônus atrelados à aquisição de certificações, ao desenvolvimento de habilidades e competências que possam ser medidas e aos resultados obtidos pelos estudantes em testes padronizados de larga escala. Ao criar entraves para que os professores assumam sua parcela de responsabilidade na produção do conhecimento e nas decisões sobre as diretrizes da educação, essas políticas e práticas acabam por obstaculizar o desenvolvimento de uma profissionalidade docente centrada na autonomia do educador.

Em tempos em que se propõe uma "base nacional curricular comum", que engessa o currículo das escolas e compromete a autonomia dos professores e que as políticas públicas de educação ainda são insuficientes para impedir processos de privatização e de sucateamento da profissão de professor, cabe perguntar qual é o poder de uma formação de educadores contra-hegemônica? Que ações podem ser gestadas no interior da formação de educadores (inicial e em serviço), tendo em vista melhor compreender e se opor a políticas e práticas desumanizadoras de educação, que afetam a sociedade de forma mais ampla e, de maneira mais direta, os docentes e os educandos nas escolas?

As respostas a essas perguntas passam, necessariamente, pelo reconhecimento e valorização da profissionalização dos professores e pela estruturação de uma formação inicial e em serviço que aproxime teoria e prática, visando à melhoria da ação político-pedagógica dos educadores nos espaços escolares, tornando-os mais democráticos, criativos, críticos e socialmente justos. 
Ao mesmo tempo, é fundamental estimular ações que vão para além dos espaços locais de formação de educadores e permitam o esforço contra-hegemônico. Isso significa fortalecer a luta coletiva dos educadores por melhores condições de trabalho e por propostas de educação que promovam a liberdade e o debate público sobre a sociedade que se quer construir, forjar alianças entre grupos de professores/pesquisadores que estão investigando e desenvolvendo práticas transformadoras de formação docente e entre esses grupos e movimentos sociais que reivindicam a implementação e ampliação de seus direitos. Por fim, mas com igual importância, não se pode prescindir da conquista de espaço na grande mídia, buscando dar visibilidade às conquistas e demandas dos educadores das escolas e universidades.

É preciso, contudo, recusar o otimismo ingênuo de que a formação de educadores é a alavanca para a transformação da escola, da educação e da sociedade, assim como o pessimismo mecanicista de que só se pode fazer alguma coisa depois de mudanças infraestruturais. Isso significa nem superestimar e nem subestimar a formação docente, assumindo-a como essencial ao desenvolvimento profissional dos educadores e à reflexão crítica sobre a opção de educação que sempre precisa ser feita e que informa e orienta a prática.

Conquistar e desenvolver novos modelos contra-hegemônicos de formação de educadores é um grande desafio que se coloca para os pesquisadores desse campo de estudo. Claro que isso não se faz de um dia para outro, pois exige grande esforço político, teórico e metodológico. No entanto, com inspiração em Paulo Freire, é preciso buscar fazer, dentro de limites históricos, o que é possível ser feito hoje, para tornar o que ainda não pode ser feito mais possível.

Os temas aqui anunciados orientaram as questões da entrevista com o professor Dr. Ira Shor, da City University of NY's Graduate Center (Phd Program in English), e do Departamento de Inglês do College of Staten Island (CSI). Ira Shor tem se dedicado ao ensino de alunos da graduação e pós-graduação, na perspectiva da educação crítica. É autor de 9 livros, dentre os quais, três focalizam o pensamento e a prática de Paulo Freire. O trabalho de Shor com Freire teve início em 1980 e se estendeu até o falecimento de Freire, em 1997. Shor e Freire são coautores do primeiro livro falado de Paulo Freire intitulado, no Brasil, Medo e ousadia: o cotidiano do professor. Nessa produção, os autores discutem, com destaque, a questão do conhecimento, do diálogo e dos fundamentos da educação libertadora, em imbricação com a formação dos professores, e a importância da inserção político-pedagógica dos educadores dentro e fora da escola. O livro de Shor, Critical teaching and everyday life, ainda sem tradução brasileira, foi a primeira obra integralmente destinada ao tratamento da pedagogia crítica de Freire no contexto norte-americano. 
Nessa entrevista, realizada em março de 2016, são apresentadas sínteses analíticas desenvolvidas pelo professor Ira Shor, decorrentes de sua ampla experiência no campo da formação de educadores, na perspectiva crítico-libertadora, e de sua militância política.

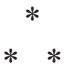

Interviewers: In the dialogical book that you wrote with Paulo Freire, $A$ pedagogy for liberation, published in 1987 , there is a very exciting chapter titled "How can teachers become liberating educators?". Almost thirty years after the publication of this book, in a given context of a "controlling" and "evaluative" State, defined by neoliberal ideology, which aspects of your proposals you would keep in relation to this theme and what would you add in this direction?

Ira Shor: In that chapter, Paulo Freire and I speak about our own formation as teachers. This is a good starting point I still recommend for all educators rethinking their teaching practice. We can learn how we learned to teach like we do. Composing professional autobiographies makes explicit our own development. Before becoming teachers, we are exposed to many years of traditional pedagogy in schools and colleges where "the banking model" of instruction dominates, where the traditional subject matters have authority. Few of us ever take part in participatory, dialogic, problem-posing, critical classrooms. This means that we start our own teaching careers always already formed by traditional instruction - teachers lecture and students do seatwork, memorize materials, respond to questions, and take tests. This is the standard model of schooling we internalize year by year as students and then repeat when we become teachers.

Traditional schooling does not invite us to practice democratic relations or to develop critical consciousness, to question the validity of the official story presented in textbooks or to challenge unequal power relations in the status $q u o$. Our writing and reading in school involves required texts and essays, and a lot of memorizing.

We become critical educators when we reflect on how traditional teaching and learning gradually occupied us in the years of our own schooling. Paulo Freire was very committed to teachers taking responsibility for their own formation and re-formation into the critical, student-centered educators required to build democracy in society. We cannot expect the traditional status quo to train us in how to question the status quo, so we educators will have to build this training despite opposition from the top down.

In our talking book from 1986, I also proposed listening carefully to students as they speak to learn how they understand the specific subject matter 
under study as well as how they perceive themselves in their world. Teaching practice should be shaped by student expression and student learning. We construct lesson plans and syllabi from the discourse and thinking students display in class, fashioning sequentially more demanding tasks based in the activities we observe.

Paulo Freire maintained that teachers must learn to respect and value the everyday idioms students bring in class, while also teaching standard usage as a tool for opposition in society against inequality, that is, teaching high-status discourse so that non-elite students gain the disposition and the linguistic tools needed to fight for social justice in their unequal society.

Teacher-talk is an authoritative, academic idiom spoke in standard usage to announce their position as the director of the classroom. This teacherly voice is generally distinct in loudness, explicitness, lexicon, syntax, accent, emphasis, and intonation from the vast majority of students. (In one of my classes, a student wrote this when I asked them to write "advice to the teacher": "Don't kill us with your voice.") The institutional voice of the teacher may be one instrument imposing what Paulo called "the culture of silence" on students because by merely speaking in their community idioms students announce or display their lower-class identities.

The conflict of idioms is part of the division Paulo saw between the teacher and the students, which he posed as the first problem in building a liberating classroom, which he understood as a mutual learning process. This is why I named one discourse goal of the critical classroom as "the third idiom." By this, I mean that non-elite students (the majority) come to class speaking non-authoritative community discourses while the teacher arrives trained in authoritative academic discourses. How do we overcome this linguistic divide? I have proposed that teachers can develop hybrid speech styles which incorporate colloquial/conversational features while conveying formal subject matters and analytic frameworks. This third idiom modeled by the teacher should be offered in ways that invite students to practice similar rhetorical moves. This rhetorical process serves democratization which pulls both teachers and students forward into the gradual invention of a converging discourse.

Paulo Freire said in our book about learning from students, "They taught me without saying that I should never dichotomize these two sets of knowledge, the less rigorous one from the more rigorous one. They taught me without saying that their language was not inferior to mine. Their syntax was as beautiful as mine."(p. 29). Further, he proposed that "Liberatory education is fundamentally a situation where the teacher and the students both have to be learners, both have to be cognitive subjects, in spite of being different. This is for me the first test of liberating education, for teachers and students both to be critical agents 
in the act of knowing."(p. 33). Paulo's critical classroom repositions the human subjects involved in it.

In the chapter you refer to, on becoming a critical educator, Paulo also emphasized the larger social context in which any subject matter or generative theme was situated: "The criticism that liberating education has to offer emphatically is not the criticism which ends at the subsystem of education. On the contrary, the criticism in the liberatory class goes beyond the subsystem of education and becomes a criticism of society." (p. 35). Paulo saw teacher-training for critical practice involving a study of power in society, particularly the capitalist power to regulate mass education, by enforcing required textbooks and testing regimes. He called this centrally-controlled curriculum a "limit situation" to liberating education against which we invent "limit-acts." The dominant or traditional curriculum masks the class-based power relations which they serve, so the task of the critical teacher is to find ways to effectively reveal what is hidden. The educator who is becoming a critical teacher recognizes, then, that education is unavoidably, a form of politics, that is, a site of power relations involving how should schooling shape students into becoming people who shape their world.

Paulo also urged in that chapter "[...] that not all kinds of lecturing is banking education" (p. 40) an important qualification to his banking metaphor (whereby teachers bank deposits of pre-formulated official knowledge into the passive minds of students). Paulo suggested what I later called "the dialogic lecture," where an extended formal presentation by the teacher verbally poses questions and materials which "illuminate reality" (Paulo's phrase). The animated presentations of the critical teacher can "critically re-orient students to society." (p. 40). Paulo urged us to practice "lecturing" in an oppositional voice which is a dynamic, unveiling instrument. Paulo described this kind of "lecture" as an "oral codification" which pictures in words a problematic condition or situation. It is an oral variation of Paulo's original pictorial "codifications" which he used to prompt discussion in his original literacy classes among peasants and workers.

Perhaps most immediate for young critical teachers is not acting alone or in isolation. Paulo often said, "You can't confront the lion alone." From the first day of teaching, we should find allies to work with and to learn from, seeking to work with groups of colleagues, not becoming singled out as a lone dissident too easily dismissed by the administration.

Paulo also insisted on the value of education inside ongoing social movements outside formal schools and colleges in the political arenas of society, where teachers had a lot offer contending organizations which in turn had a lot to offer them. Paulo's emphasis on social movements as sites of teaching and learning is very important. I have always been involved in social movements 
before and after I became a teacher. Paulo Freire, of course, was involved in social movements before the terrible coup of 1964 which forced him out of Brazil, and then again after he returned to Brazil in 1980.

I connect the politics of critical teaching with the politics of protest in society by saying that "Classrooms cannot be managed from the outside and cannot be defended from the inside." By this, I mean that outside authorities invade classrooms with required curricula, mandates tests, pre-set syllabi, and standardized testing. These distant authorities micro-manage teaching and learning in the classroom so as to control the development of students and to limit the professional autonomy of educators. Professional educators must be allowed to design student-centered, locally-situated creative and critical learning programs in their classrooms. Control from outside authorities is anti-educational, undemocratic, and bureaucratically suffocating. To win the power to control the inside process of the classroom, teachers and students have no choice but to protest together outside the classroom to stop the abusive invasion of their work by state and corporate authorities.

Interviewers: Brazil strides to establish and implement, with the force of law, one Common Curriculum National Base, very similar to the Common Core in the United States. What is your evaluation on this type of curriculum policy? What is the strength and weakness of this kind of proposal?

Ira Shor: In the United States, the Common Core is a disaster for teaching and learning. It undermines public education by centralizing the curriculum so that standardized commercial testing can be used as the only measure of achievement by students, teachers, and schools. Common Core is the latest policy to unify the national curriculum under central state control in an even grander power grab outside the classroom.

Test scores based on the Common Core here have fallen drastically in the public schools forced to adopt this curriculum and this testing regime. The artificially depressed scores justify an official myth pushed by government and business that our public schools have failed and must be closed down and reorganized on a different system of privatization.

Common Core in the U.S. is thus a neoliberal project to centralize, standardize, privatize and marketize public education. With a central curriculum, high tech and education companies can sell their goods and services at great scale thanks to a nationally unified market for educational vendors. This nationally unified education market is of great value as a revenue stream to testing and to publishing giants like Pearson and Microsoft, who sell hardware, software, bandwidth, online tests, online assessment, online reporting, online teaching, etc. Once again, the porous walls of each classroom are being invaded from the 
outside as teaching and learning leaves control of professional educators and enters the control of capitalists known here as "edupreneurs."

Regarding online tools, for twenty years, scholars have asked, "Where is the research showing that online learning or digital programs enhance student achievement?", "Where is the data proving that the many billions already spent on tech buys have produced more learning?". Similarly, there is no research justifying billions spent on standardized testing to improve student achievement. The $\$ 650$ billion per year U.S. national budget for public schools is the target of commercial interests who insist that everything must be "data-driven" (except proof of their own claims and the value of their own products).

Nationalized curriculum and testing are neoliberal campaigns to capture the revenue stream from public education and to facilitate privatization. One goal of neoliberal education policy in unifying, centralizing, standardizing, and privatizing education is the transfer of public funds to private hands. The public schools are being reorganized to make them into a continuous revenue stream for private companies. A second goal of this policy is to sabotage teacher unions and lower the wage costs of public schooling. Two unions in the U.S. now represent over 3 million teachers. A centralized curriculum developed outside classrooms can be injected online in daily lessons by low-skill, low-wage instructors. This digitized national curriculum and national testing greatly reduces the pedagogical expertise required of teachers; it enables replacing expensive veteran teachers with young, cheap new hires. The private organization leading this displacement of veteran teachers is known here as Teach for America.

Central control and standardization also restrict teachers' chances to include critical learning in their lessons. High-stakes commercial testing narrows curriculum to teaching to the tests because so much depends on high scores by students on the centrally-mandated tests. The negative effects on teaching and learning from high-stakes testing are apparent: Narrowing curriculum to materials on the tests and encouraging local cheating to produce false high scores. This Common Core policy nationally unified curriculum via two testing groups immediately organized to produce testing: the Partnership for Assessment of College and Career Readiness (PARCC), and the Smarter Balanced Assessment Consortium (SBAC or "Smarter Balanced").

Interviewers: What possibilities have educators and communities that take an educational perspective committed to the paradigm of liberating education, to react to policies of evaluation and curriculum standardization? What would you suggest to this confrontation?

Ira Shor: Opposition to the neoliberal centralization and standardization policies of both major capitalist parties has been large and growing from the 
bottom up. A movement of opposition parents has been especially effective in defending schoolchildren against the authorities who abuse students with many hours of testing. This parents' movement is called "Opt-Out." The parents send formal letters to the school principal of their children's school indicating that their kids will not participate in any standardized testing, explaining their justification for doing so. Sample letters for parents' circulate widely online. Local groups assist parents in opting-out their children. A vigorous network of online websites maintain daily discussions among parents, teachers, dissident administrators, and education professors. The daily online activity is phenomenal along with opposition meetings, citywide rallies, statewide protests and national conferences and marches. I post on these websites and have spoken at rallies and conferences, and worked with a local opposition group to spread opt-out in my school district.

We need more organized opposition from teachers. Nationally, the two teacher unions suppress teacher activism, the American Federation of Teachers (led by Randi Weingarten) and the National Education Association (led by Lily Eskelsen-Garcia). Both leaders accept, accommodate to and enforce the neoliberal agenda of the status quo. They both take money from billionaire capitalists like Bill Gates of Microsoft to help promote the Common Core. Both union leaders are high-level insiders in the Democratic Party which aggressively pursue pro-corporate policies. Both rule their unions undemocratically, forcing early endorsements of the Wall Street Presidential candidate Hillary Clinton. For mass education and the public sector to be rescued from standardization and privatization, both Weingarten and Eskelsen must be driven from office. There are rank-and-file groups challenging the leadership of the AFT, one in New York called the Movement of Radical Educators. An alliance of parents, teachers, and students for democracy and equality, for local autonomy and adequate funding, will be needed to turn back this private war on public education.

Interviewers: How does the curriculum standardization and the homogenization of the schools' context affects pre-service and in-service teacher education and the teachers' work?

Ira Shor: In the USA, graduate schools of teacher education are losing students because teachers and teaching are under constant attack. Teaching is known here as a profession of hard work, low pay, disrespect, low autonomy, and high risks. Public school teachers are generally the poorest-paid college graduates in the professional workforce, along with social workers, the vast majority of both being female. For the last 25 years, neoliberal politicians and wealthy billionaires have been financing alternative routes to teaching and administration to bypass and undermine graduate education programs at uni- 
versities. The most-famous alternative teacher route is one I mentioned above, Teach for America, formed in 1990 by Wendy Kopp to funnel young recent graduates of elite colleges to poor schools. This seemingly idealistic project has grown enormously; its bank account is $\$ 400$ million which funds 5-week training classes for thousands of 22-year-old college grads, who stay at their public schools for only 2-3 years and then move on to better-paying careers in school and civic administration, in Wall Street, in private corporations, or go on to law school. The success of TFA undermines graduate teacher-education programs because TFA offers a starting job in a school after only 5 weeks of summer training. This TFA pipeline de-professionalizes teaching as a career.

There has also been in the U.S. heavily-financed alternative routes to educational administration. The most famous is the one financed by the billionaire Eli Broad, the Broad Academy, an unaccredited organization. It recruits former TFA graduates as well as business-minded executives of all kinds for residential training in "the Broad Playbook," which is a guide detailing step-by-step community management to engineer districts towards a test-based centralized curriculum. Broad graduates occupy district superintendents' offices, municipal departments of education, state-level commissions, and the federal Department of Education, whose recently-retired leader Arne Duncan was a Broad product. The vast public education system in the U.S. - 14,000 school districts - has posed a monumental task to neoliberal forces in the area of cadre development of executives needed to implement policy changes.

Interviewers: Often, there is a discourse among those responsible for the elaboration of the public educational policies and the "corporate reformers" that curricular "packages" or "kits" are important and valid resources to support the teachers' practice, ensuring the quality of educational work. How to argue against this speech? How teachers could be more active in decisions about the educational policy?

Ira Shor: Kits? Packages? Sounds like more profiteering by commercial vendors who sell goods and services to public school districts. Much better to spend the money on smaller classes, more hands-on experimental learning, and more intensive teacher development. There is solid research confirming that small classes enhance student learning, especially among minority and poor students. "Small class size" is the first "kit" government should provide teachers, students, and families. The second "kit" is stable, affordable housing for all families. Poverty is the great unacknowledged problem in education. $23 \%$ of U.S. children now live beneath the poverty line. An "anti-poverty kit" should add food, clothing, and medical care to the students most in need. 
Kits and packages are what we call here "teacher-proofing" the curriculum. Neoliberals who want greater management control of professional educators at lower cost, and education traditionalists who favor Core Knowledge based on canonical books and themes, push such kits. The premier kit-maker of the last 30 years in the U.S. has been E.D. Hirsch who published a series of books on what children in every grade must know, in addition to a children's dictionary of "cultural literacy" based on a list of 5,000 traditional items he published first in 1987. Curriculum "kits" and "packages" are management tools to control the costs, autonomy, and outcomes of schooling.

"Kits" arrive as a "solution" after a long period of propaganda about the failures of public schools. For the last 4 decades in the U.S., a constant negative narrative has poured out of government, mass media, conservative pundits, foundations, and corporate leaders, that "public education is a failure because teachers don't care, teacher unions protect bad teachers from being fired, and parents are not allowed choice in picking what school their kids should attend." This neoliberal storytelling does not include growing poverty, stagnating family wages, overwork and underpay, unaffordable housing, large class size, crumbling infrastructure, or racist segregation as factors in the fate of public schools. This official story of school failure puts the public sector on the defensive, preparing the way for "kits" and "packages."

But, the best way to ensure teacher competency at school is to invest in small classes, intense tutoring services for students, parent involvement in each school, and robust professional development. Each school must have a professional development plan which assigns to teachers themselves the task of observing, evaluating, and improving classroom practice of their peers. Parents and students should be involved in this process as stakeholders for quality teaching and learning. We already have a strong research literature on professional development that works.

Interviewers: In Brazil, research indicates that, despite the efforts that have been done and the crucial role of the universities on teacher education, initial teacher education still has left significant gaps in the seizure of specific knowledge of the areas, and has not privileged didactics and teaching practice in the curriculum. In addition to identifying these gaps, it appears that teacher education (pre-service and in-service) continues to have a technical character, close to what has been characterized by Paulo Freire as "banking education". What could be done to improve the experience that teachers are getting to work at schools, in order to have a progress towards a critical and transformative education with social quality? 
Ira Shor: I visited Paulo Freire in Brazil in 1986 and spoke to a graduate class at Sao Paulo University. He mentioned a debate underway then about "pedagogy of contents" which was being posed against his "pedagogy of the oppressed." The opposition to Paulo then emphasized "contents" to elevate hard subject matter in the school curriculum rather than student-centered critical learning methods. A similar campaign was underway here in the 1980s, led by the scholar named above, E. D. Hirsch, along with others like Mortimer Adler, Diane Ravitch, and Chester Finn. That debate led to a ferocious "culture war" about how to teach the history of our country. Liberal, feminist, multicultural, and labor advocates on one side proposed non-traditional contents for a critical narrative of national formation, while conservative, traditional, and corporate advocates insisted on a mainstream narrative of the great events, great people, and wonderful things accomplished. This curriculum war grew so intense that by the early 1990s, subject matter or "the pedagogy of contents" was too toxic for any education reform from Washington or state capitals. Instead, since 2002, successive national reforms have emphasized two skill-based activities onlyreading and mathematics. The current Common Core attempt to unify curriculum apparently tests only skills, not contents, in reading and math, but canonical or traditional contents will be slipped in the back door, via the reading selections used on the standardized tests.

A frontal advocacy of traditional subject matters is now avoided here in favor of "skills." However, there has been a long crisis in the liberal arts, beginning 45 years ago when university liberal arts programs housed the most dissident elements in that period of mass movements. Closing down the large protest culture of that time involved restricting liberal arts, which made those subject matters the target of budget cuts. The policy environment now remains toxic to training teachers in humanities disciplines because those areas are most open to critical thought and oppositional analysis. The corporate neoliberal capture of higher education is hostile to critical thinking about power in school and society. A neoliberal state is building a neoliberal university which trains graduates in narrow occupations emphasizing technical expertise in a specific professional employment. Narrowly-trained, compliant professionals who don't question authority are the employees of choice, including the employees of schools, like teachers. Thus, the triumph of neoliberalism includes a triumph over teacher-education to favor "banking" practices which funnel pre-set, approved kits of knowledge to students. The task of critical educators then, is to oppose this dehumanizing narrowness in forming professional educators. Spaciously trained teachers should be graduated as educators who can develop civic-minded students able to rescue and re-make their toxic planet and cruel societies. 
Teachers are at the bottom of a formidable bureaucracy which suffocates their autonomy, creativity, and critical talents. To confront these limits, teachertraining should graduate change-agents in school and society. Study "changeagency" as part of the pre-service and in-service programs, that is, how do teachers act to change their own practice as well as those of the institutions they work in? Study how people in various places at various times collaborated to effect change. "Change-agency" is not now part of teacher education programs yet it is essential knowledge. For certain, new teacher programs should study how children learn, how mass education grew and how it now functions. But, perhaps most of all, teacher-training should inspire in students "a passion for knowing the world," as Paulo Freire's daughter Madalena entitled her book.

Interviewers: To close our dialogue, we would like you to tell us how was your first encounter with Paulo Freire. We would also like to know about possible influences of Freire's work in your role as a researcher-teacher and political activist? And lastly, do you consider that Freire's pedagogy is relevant nowadays to teacher education?

Ira Shor: My first encounter with Paulo Freire was in a student restaurant in Amherst, Massachusetts, in February 1984. The year before, Paulo had written a letter to me after he read my book Critical teaching and everyday life, which was the first book in the U.S. discussing a Freire-based critical pedagogy. When I opened my mailbox and saw an aerogramme from Brazil, I was very surprised. When I saw Paulo Freire's name on the return address, I was amazed. When I opened the aerogramme and read Paulo's very kind words, I was thrilled. He thanked me for "the beautiful words" of my book. Six months later he was at Stanford University and called me from Palo Alto, asking me join him in his seminar there. I couldn't travel then, so Paulo told me he would be in residence in Amherst at the University of Massachusetts in the coming year, and could I join him there? I immediately said yes.

In February 1984, I traveled to Amherst and followed his instructions to a roadside pizza parlor. I saw his face through the windows at a table full of students. When I entered, he stood and hugged me, and had me sit down next to him. We talked and Paulo asked me to join him onstage the next day for his presentations, overwhelming with his generosity. The next day, when I came onstage, he introduced me as "his son," an honor that overwhelmed me again. Paulo gave me a great gift which I felt I could return to him only by working as hard as I could for as long as I could for social justice.

I made two other trips to Amherst that month to see him, and when I proposed to Paulo that we co-author a book on the questions North American teachers ask most about becoming critical educators, he said, "Let's begin to- 
morrow!" For the next two years I traveled wherever Paulo was in the North to work on the book with him, and in 1986 we published what he called his first "talking book," known in English as A pedagogy for liberation, in Brasil as Medo e ousadia: o cotidiano do professor, still in print 30 years later, translated into Hebrew, Chinese, and Greek.

Paulo's writings and conversations taught me how to understand policy, history, foundations, and the relation of power to education and classroom practice. Perhaps most of all, that education is politics, that all pedagogies are political, all methods for teaching and learning form human subjects, all choices about topics, readings, and discourse in the classroom construct people who bring into being their world.

Paulo's work is relevant for critical educators today. Education is more political than ever; power relations are invading classrooms like never before.

Paulo insisted that all teaching practice must be situated in the actual conditions where we work for the actual students we work with, so there is no single model or standard model of critical teaching that should be copied everywhere. Paulo urged reinventing his pedagogy for the realities of our times and places. He said, "The best way to follow me is not to follow me."

We need to expand critical pedagogy as a category including many kinds of themes, approaches, subject matters, constitutencies, and locations in and out of schools-feminist pedagogy, anti-racist teaching, social justice curricula, themes of sexual preference and heterosexism, environmentalism, and the use of digital tools for democratic activism.

Paulo opposed standardized curricula and bureaucratic testing; students had to be cognitively active as researchers and co-developers of classroom inquiry; education was responsible above all for humanization, to make us always more fully human, by which Paulo understood being human as an orientation towards compassion, cooperation, curiosity, freedom, tolerance, playfulness, humor, love, and justice... to counter the dehumanizing effects of unequal domination by the cruel elites now ruling all societies.

All in all, then, I would say that humanization and social justice, the underlying themes of Paulo Freire's work, remain as relevant today as always. A humane world that is less cruel and more just was Paulo Freire's lifelong dream. Paulo dreamed of such a world but he worked for it too, his feet firmly planted in the facts of history. There was for him "the power now in power" arrayed against "the power not yet in power." He knew which side he was on, and so do we. 


\section{Publicações do autor (seleção)}

FREIRE, P.; SHOR, I. A pedagogy for liberation: dialogues on transforming education. Santa Barbara: Bergin-Garvey/Greenwood, 2002.

FREIRE, P.; SHOR, I. Medo e ousadia: o cotidiano do professor. São Paulo: Paz e Terra, 2008.

SHOR, I. Critical teaching and everyday life. Chicago: University of Chicago Press, 1992.

SHOR, I. Culture wars: school and society in the conservative restoration. Chicago: University of Chicago Press, 1992.

SHOR, I. When students have power: negotiating authority in a critical pedagogy. Chicago: University of Chicago Press, 1998.

SHOR, I. Empowering education: critical teaching for social change. Chicago: University of Chicago Press, 2000.

SHOR, I. (Org.). Freire for the classroom: a sourcebook for liberatory teaching. Portsmouth: Boynton-Cook/Heinemann, 2002.

SHOR, I.; PARI, C. Critical literacy in action: writing words, changing worlds - a tribute to the life and work of Paulo Freire (1921-1997). Portsmouth: Boynton-Cook/ Heinemann, 1999.

SHOR, I.; PARI, C. Education is politics: critical teaching across differences (K-12). v. 1. Portsmouth: Boynton-Cook/Heinemann, 1999.

SHOR, I.; PARI, C. Education is politics: critical teaching across differences (PostSecondary). v. 2. Portsmouth: Boynton-Cook Heinemann, 2000.

Texto recebido em 22 de maio de 2016.

Texto aprovado em 23 de maio de 2016. 